\title{
Pharmacokinetics of ranitidine in critically ill patients
}

K. F. ILETT, R. L. NATION*, R. TJOKROSETIO, W. R. THOMPSON, T. E. OH \& P. D. CAMERON Combined Unit in Clinical Pharmacology and Toxicology, Department of Pharmacology, University of Western Australia and Intensive Care Unit, Sir Charles Gairdner Hospital, Nedlands, Western Australia

1 The plasma pharmacokinetics of ranitidine $(50 \mathrm{mg}$ i.v.) have been studied in 17 critically ill patients in an intensive care unit. Measurements of gastric aspirate $\mathrm{pH}$ were also made in 16 of these patients. Ranitidine therapy was part of the patients' normal drug regimen.

2 Ranitidine plasma concentration was measured by high performance liquid chromatography and appropriate polyexponential equations were fitted to concentration-time data to enable calculation of relevant pharmacokinetic parameters. Values of the volume of the initial dilution space (median $=89 \mathrm{ml} \mathrm{kg}^{-1}$ ) and volume of distribution at steady state (median $=1.541 \mathrm{~kg}^{-1}$ ) were about $60 \%$ of corresponding mean literature values for healthy controls. Plasma clearance (median $=4.22 \mathrm{ml} \mathrm{min}^{-1} \mathrm{~kg}^{-1}$ ) and terminal half-life (median $=4.7 \mathrm{~h}$ ) were about 2-3 fold less and 2-3 fold greater, respectively, than values for healthy controls. There was wide interpatient variation in all the pharmacokinetic parameters. Renal impairment was considered to be largely responsible for the low plasma clearance.

3 Gastric aspirate $\mathrm{pH}$ was measured at 0,1 and $7 \mathrm{~h}$ after ranitidine administration and $58 \%$ of samples were found to be above $\mathrm{pH} 4$. Four patients had gastric $\mathrm{pH}$ values which were consistently below $\mathrm{pH} 4$ despite average trough plasma ranitidine concentrations equal to or greater than those required for a $50 \%$ suppression of gastric acid secretion in normal volunteers.

Keywords ranitidine plasma pharmacokinetics critically ill patients gastric aspirate $\mathrm{pH}$

\section{Introduction}

Ranitidine is a potent histamine $\mathbf{H}_{2}$-receptor antagonist which is used in the treatment of peptic ulcer (Brogden et al., 1981) and in the prevention of stress-induced ulceration in critically ill patients (Barth et al., 1984), although the use of histamine $\mathrm{H}_{2}$-receptor blockers in this latter patient group is controversial (Greene et al., 1984). After intravenous administration ranitidine is largely excreted by the kidneys (McNeil et al., 1981). The pharmacokinetics of the drug have been studied extensively in normal volunteers (Garg et al., 1981; Lebert et al., 1981a; McNeil et al., 1981; Van Hecken et al., 1982; McGonigle et al., 1982; Young et al., 1982; Chau et al., 1982) and in selected patient groups with renal (Meffin et al., 1983; McFadyen et al., 1983) or hepatic (Young et al., 1982; Smith et al., 1984) disease. There are, however, no published data on the pharmacokinetics of ranitidine in the critically ill and thus the present study was

* Present address: School of Pharmacy, South Australian Institute of Technology, Adelaide, South Australia. Correspondence: Dr K. F. Ilett, Department of Pharmacology, University of Western Australia, Nedlands, Western Australia 6009. 
undertaken to assess ranitidine plasma kinetics and gastric $\mathrm{pH}$ effects within this patient group.

\section{Methods}

Seventeen critically ill patients being cared for in the Intensive Care Unit took part in the study which was approved by the Human Rights Committee of The University of Western Australia. Ranitidine therapy was part of the patients' normal drug regimen. Their clinical and biochemical details are summarised in Tables 1 and 2. Most had multiple diagnoses and all were receiving several other medications (range 7-16) in addition to ranitidine. Ranitidine was the sole anti-ulcer therapy in all but patient IT who also received antacid via a nasogastric tube.

\section{Ranitidine administration and collection of blood and gastric fluid samples}

Patients were receiving intermittent intravenous infusions of ranitidine. One patient was studied after the first dose of ranitidine while the remaining patients were studied after being on continuous ranitidine therapy for a mean of 5.5 days (range 1-15 days). Prior to study, 14 patients received $50 \mathrm{mg}$ ranitidine (Zantac, Glaxo, Australia) intravenously every $8 \mathrm{~h}$ while two patients received $25 \mathrm{mg}$ ranitidine 8 and 12 hourly, respectively. On the study day, $50 \mathrm{mg}$ ranitidine (in $10 \mathrm{ml}$ normal saline) was administered as an intravenous infusion over $3.93 \pm$ 0.20 min (mean \pm s.e. mean) by means of a constant rate infusion pump.

Arterial blood samples $(2.5 \mathrm{ml})$ were collected from each patient through an indwelling catheter already located in the radial artery for measurement of blood pressure and blood gases. Samples were taken immediately before the ranitidine dose and at 1,3,4 (or end of infusion), $6,10,15,20$ and $30 \mathrm{~min}$ and at $1,2,3,4,6$ and $8 \mathrm{~h}$ after dosage. The samples were collected into heparinised polypropylene tubes and after being separated by centrifugation, plasma was stored at $-20^{\circ} \mathrm{C}$ until assayed for ranitidine. In all patients except IT, gastric fluid was aspirated from an in situ nasogastric tube at 0,1 and $7 \mathrm{~h}$ after dosage and its $\mathrm{pH}$ was measured using a digital $\mathrm{pH}$ meter. In six patients, $2-5$ additional $\mathrm{pH}$ measurements were made on gastric aspirates obtained at various times from 2 to $8 \mathrm{~h}$ after dosage.

\section{Ranitidine analysis}

Ranitidine was measured by high performance liquid chromatography (h.p.l.c.). Aliquots of plasma $(1 \mathrm{ml})$ were mixed with $0.16 \mu \mathrm{g}$ of internal standard (AH20480; $N$-methyl- $N^{\prime}$-[3-[(3-dimethylaminomethyl)phenoxy]propyl]-2-nitro-1, l-ethylenediamine hydrochloride) and $0.05 \mathrm{ml}$ of $2 \mathrm{M} \mathrm{NaOH}$ and then extracted with $4 \mathrm{ml}$ of ether : chloroform : isopropyl alcohol $(2: 1: 1)$ by vortexing for $1 \mathrm{~min}$. After centrifugation, $3.5 \mathrm{ml}$ of the organic phase was removed and backextracted into $0.1 \mathrm{ml}$ of $5 \%$ acetic acid by vortexing for $1 \mathrm{~min}$. After a further centrifugation, the organic phase was discarded and $40 \mu \mathrm{l}$ aliquots of the acetic acid extract were injected onto the h.p.l.c. column. Approximate retention times for AH20480, desmethylranitidine and ranitidine were $3.5,4.0$ and $5.4 \mathrm{~min}$, respectively, and there was no interference from other drugs which the patients received. Despite their relatively close retention times, baseline resolution between ranitidine and $N$-desmethylranitidine was achieved largely because of the very narrow peaks which are characteristic of the procedure. The coefficient of variation for the assay was $3.5 \%$ at $0.043 \mathrm{mg} \mathrm{l}^{-1}$ and $3.1 \%$ at $1.30 \mathrm{mg} \mathrm{l}^{-1}$ $(n=6)$ with a limit of detection for ranitidine of about $0.01 \mathrm{mg} \mathrm{l}^{-1}$ plasma.

\section{Pharmacokinetic and statistical analysis}

With the exception of the one occasion on which the first dose of the ranitidine regimen was studied, the contribution to the plasma ranitidine concentrations from previous doses was subtracted by use of the superposition principle. The following equation was then fitted to the plasma ranitidine concentration-time data using the nonlinear least squares programme NONLIN (Metzler, 1974):

$$
C=\sum_{\mathrm{i}=1}^{\mathrm{n}} \frac{C_{\mathrm{i}} \mathrm{R}_{\mathrm{o}}\left(e^{\lambda_{\mathrm{i}} \mathrm{T}}-1\right)}{\lambda_{\mathrm{i}}} \cdot e^{-\lambda_{\mathrm{i}} t}
$$

where $C=$ plasma ranitidine concentration at time $t$, the time after start of infusion, $\mathrm{R}_{\mathrm{o}}=$ infusion rate, $C_{\mathrm{i}}=$ dose-independent coefficient for the ith exponential, $\lambda_{i}=$ the ith exponential and $\mathrm{T}=$ infusion time.

The polyexponential equation that best described the data for each subject was chosen on the basis of the distribution of residuals and on a visual inspection of the goodness of fits. The coefficients and exponents of the chosen equation were used for the calculation (Wagner, 1976) of the following parameters: volume of the initial distribution space $\left(V_{1}\right)$, volume of distribution at steady state $\left(V_{\mathrm{ss}}\right)$, total systemic plasma clearance $(\mathrm{CL})$ and terminal disposition half-life $\left(t_{1 / 2}\right)$. 


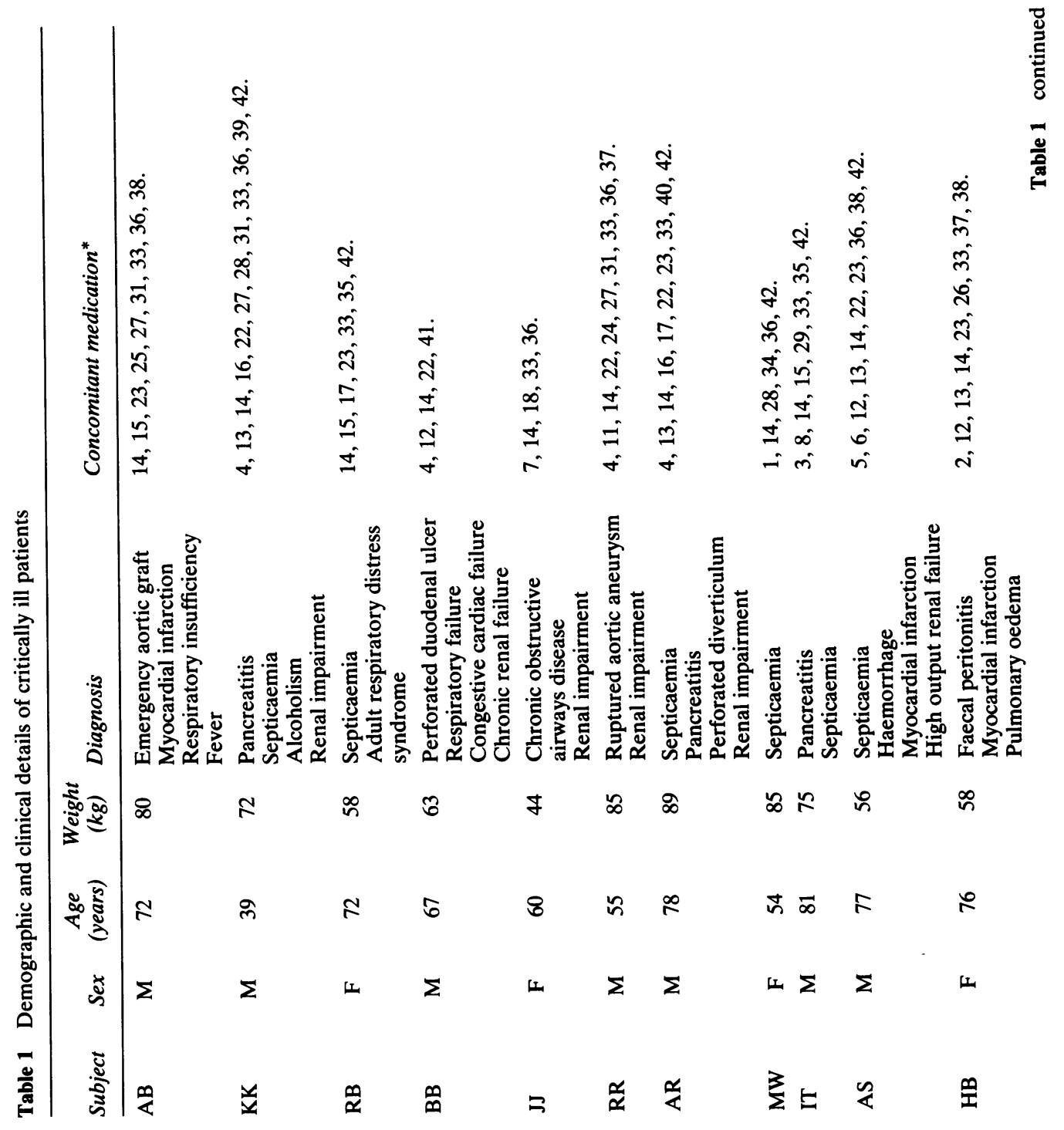




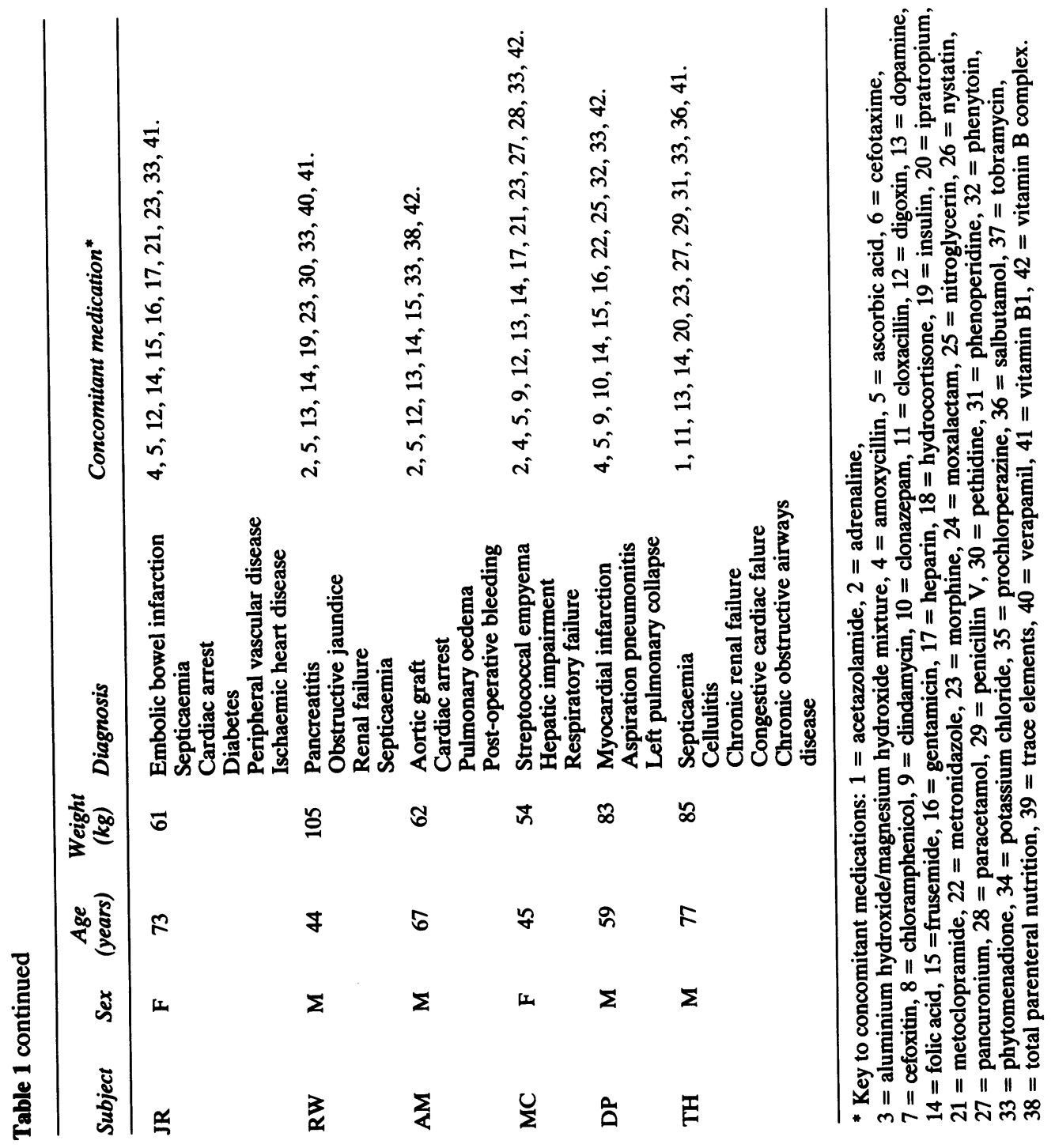




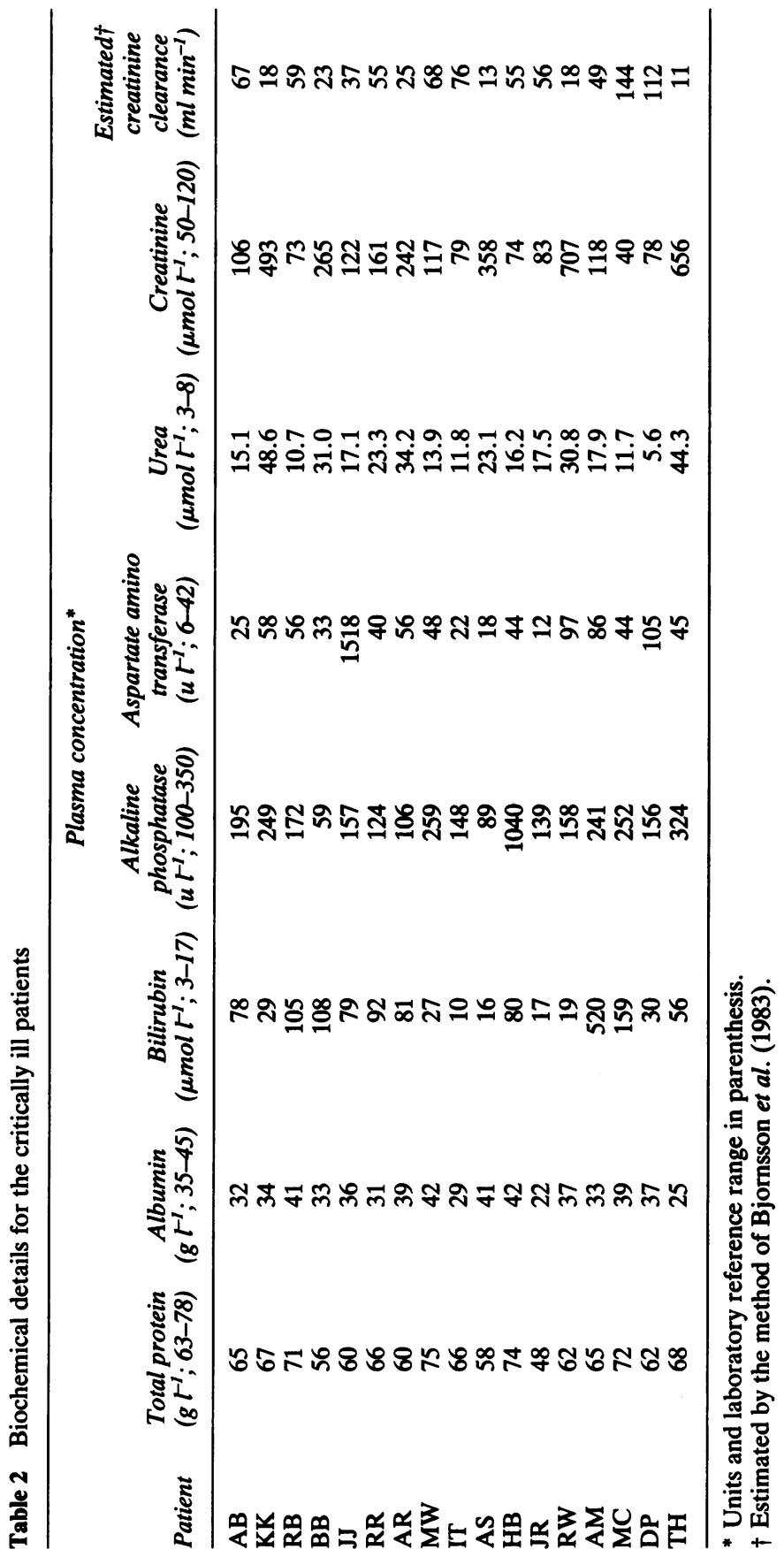


Group data were expressed either as median (and range) or as mean \pm s.e. mean unless otherwise indicated. Differences between group means were assessed by use of Student's $t$-test. Statistical association between variables was assessed by linear regression analysis. A probability value of less than 0.05 was considered significant.

\section{Results}

Analysis of the plasma concentration-time profiles indicated that in 13 of the studies, a triexponential curve was required to best represent the data while a biexponential curve was chosen in the remaining four studies. A typical profile is shown in Figure 1. At the end of the infusion, the actual mean arterial plasma ranitidine concentration was $4.59 \mathrm{mg} \mathrm{l}^{-1}$ (range $1.47-8.39 \mathrm{mg} \mathrm{l}^{-1}$ ) and at $8 \mathrm{~h}$ after dosage the mean concentration was $0.26 \mathrm{mg} \mathrm{l}^{-1}$ (range 0.04-1.76 $\mathrm{mg} \mathrm{l}^{-1}$ ). Mean ratio of the actual plasma drug concentration at the end of infusion to that at $8 \mathrm{~h}$ was 37 with a range from 2 to 124 .

The pharmacokinetic parameters describing the disposition of ranitidine are summarized in Table 3. There was a wide inter-patient variation in all parameters which reflects the diversity of the group with respect to factors such as age, concurrent pathological states and other medications. Correlations between the various pharmacokinetic parameters and age were tested but none was significant with or without correction of the parameters for body weight. Without correction for body weight, the correlation between ranitidine plasma clearance and estimated creatinine clearance was not significant $(r=0.439, P>0.05)$. There was, however, a weak but significant correlation between weight corrected ranitidine plasma clearance and estimated creatinine clearance $(y=0.028 \times$ $+2.89 ; r=0.537, P<0.05$ ).

Figure 2 shows gastric aspirate $\mathrm{pH}$ in the six patients in whom more than three $\mathrm{pH}$ measurements were made during the dose interval. Subject TH was studied after the first dose of ranitidine whereas the other five patients shown in Figure 2 were studied after being on a thricedaily ranitidine regimen for between 2 and 15 days. In the remaining 10 patients in the study group, gastric aspirates were only obtained at 0 , 1 and $7 \mathrm{~h}$ after dosage. Considering only the 0,1 and $7 \mathrm{~h}$ pH data from all 16 patients (excluding the $0 \mathrm{~h} \mathrm{pH}$ for subject $\mathrm{TH}), 58 \%$ of gastric aspirate samples had a $\mathrm{pH}$ above 4 with a corresponding mean actual plasma ranitidine concentration of $0.41 \mathrm{mg} \mathrm{l}^{-1}$, while the remaining $42 \%$ were below $\mathrm{pH} 4$ and the corresponding mean plasma ranitidine concentration was $0.38 \mathrm{mg} \mathrm{l}^{-1}$. Patients KK, AR, HB and RW had gastric pH values which were consistently less than 4 despite trough (average of the 0 and $8 \mathrm{~h}$ concentrations) plasma ranitidine concentrations during the

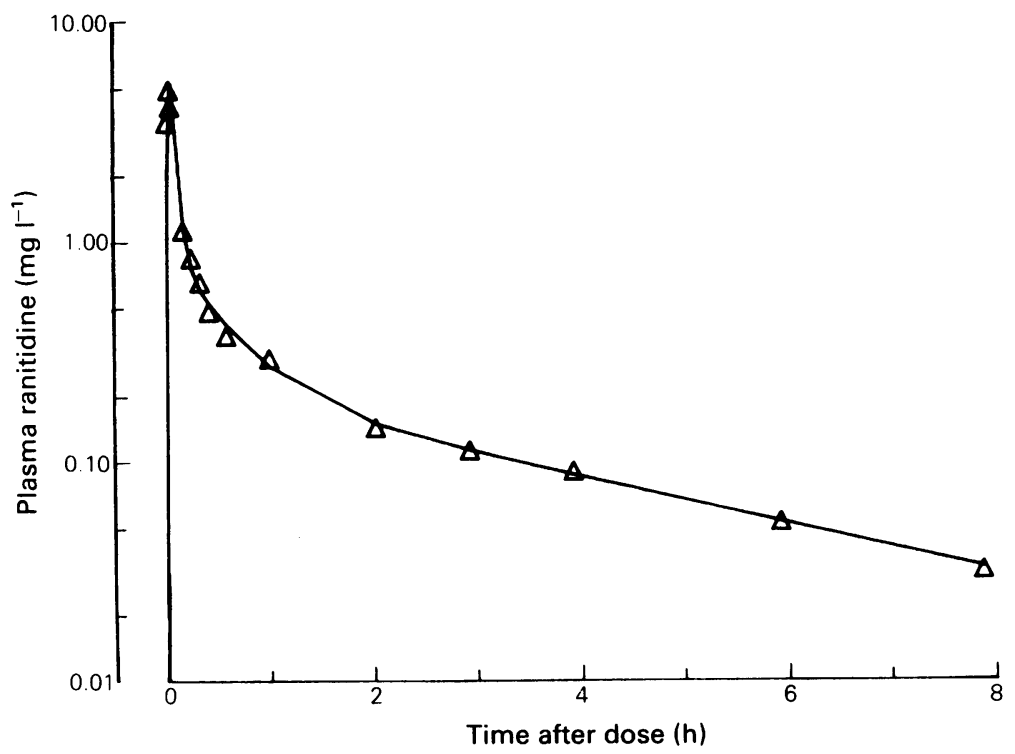

Figure 1 Typical plasma ranitidine concentration (log scale) vs time profile (Subject DP). The solid line is the computer-generated triexponential fit to the data. 
Table 3 Pharmacokinetic parameters for critically ill patients receiving ranitidine (50 mg i.v.)

\begin{tabular}{|c|c|c|c|c|c|c|c|}
\hline Patient & $\begin{array}{l}\mathrm{V}_{l} \\
(l)\end{array}$ & $\begin{array}{c}\mathrm{V}_{1} \\
\left(m g k g^{-1}\right)\end{array}$ & $\begin{array}{l}\mathrm{V}_{s s} \\
(l)\end{array}$ & $\begin{array}{c}\mathrm{V}_{s s} \\
\left(l k^{-1}\right)\end{array}$ & $\begin{array}{c}C L \\
\left(m l \min ^{-1}\right)\end{array}$ & $\begin{array}{c}C L \\
\left(\mathrm{ml} \mathrm{min}^{-1} \mathrm{~kg}^{-1}\right)\end{array}$ & $\begin{array}{l}t_{1 / 2} \\
(h)\end{array}$ \\
\hline AB & 8.5 & 106 & 148.8 & 1.86 & 737 & 9.21 & 3.5 \\
\hline KK & 13.9 & 193 & 151.6 & 2.11 & 206 & 2.86 & 10.6 \\
\hline RB & 1.9 & 33 & 58.5 & 1.01 & 253 & 4.36 & 4.0 \\
\hline BB & 1.1 & 17 & 137.8 & 2.19 & 69 & 1.10 & 23.6 \\
\hline JJ & 1.8 & 41 & 43.9 & 0.99 & 153 & 3.48 & 3.9 \\
\hline $\mathbf{R R}$ & 13.2 & 155 & 384.3 & 4.52 & 313 & 3.68 & 17.0 \\
\hline AR & 9.4 & 106 & 158.0 & 1.78 & 323 & 3.64 & 6.7 \\
\hline MW & 7.6 & 89 & 72.7 & 0.86 & 435 & 5.12 & 2.6 \\
\hline IT & 69.3 & 924 & 170.5 & 2.27 & 381 & 5.08 & 6.0 \\
\hline AS & 27.1 & 484 & 86.0 & 1.54 & 328 & 5.86 & 3.5 \\
\hline HB & 4.8 & 83 & 34.6 & 0.60 & 245 & 4.22 & 1.9 \\
\hline JR & 3.5 & 57 & 60.1 & 0.99 & 210 & 3.45 & 5.1 \\
\hline RW & 14.5 & 138 & 88.8 & 0.85 & 192 & 1.83 & 5.7 \\
\hline AM & 1.6 & 26 & 268.5 & 4.33 & 326 & 5.25 & 12.3 \\
\hline MC & 6.4 & 119 & 87.1 & 1.61 & 305 & 5.65 & 4.4 \\
\hline DP & 6.0 & 72 & 73.6 & 0.89 & 509 & 6.13 & 2.8 \\
\hline TH & 4.7 & 55 & 88.5 & 1.04 & 263 & 3.09 & 4.7 \\
\hline Median & 6.4 & 89 & 88.5 & 1.54 & 305 & 4.22 & 4.7 \\
\hline Range & $1.1-69.3$ & $17-924$ & $34.6-384.3$ & $0.60-4.52$ & 69-737 & $1.10-9.21$ & $1.9-23.6$ \\
\hline
\end{tabular}

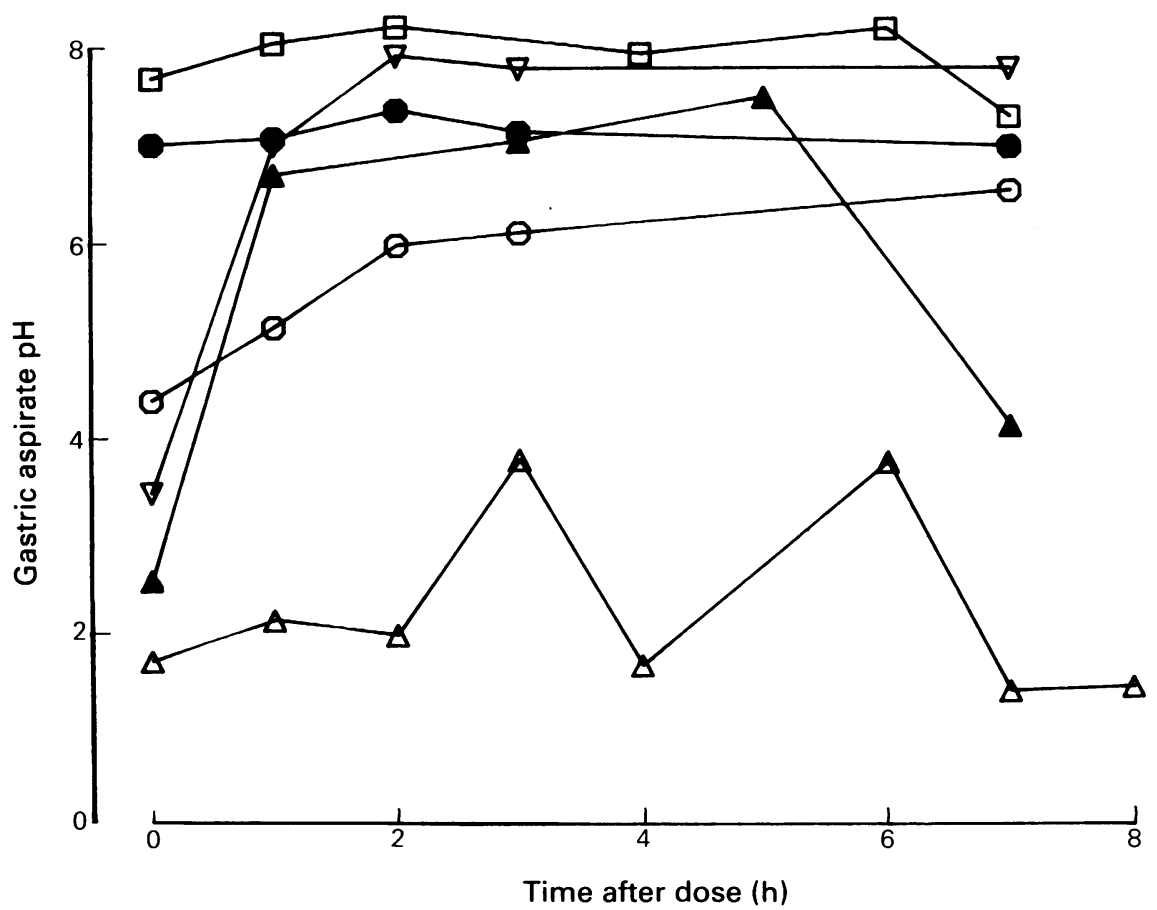

Figure 2 Gastric aspirate $\mathrm{pH}$ at various times during the ranitidine dose interval for subjects $\mathrm{HB}(\triangle)$,

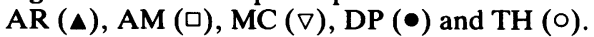


study dose interval of $0.097,0.21,0.26$ and $0.45 \mathrm{mg} \mathrm{l}^{-1}$, respectively. Three of these four patients had common diagnoses of renal impairment, pancreatitis and septicaemia (Table 1).

\section{Discussion}

Our critically ill patients had $V_{\text {ss }}$ values ranging from 34.6 to 384.31 (median $=88.51$ ) or from 0.60 to $4.521 \mathrm{~kg}^{-1}$ (median $=1.54 \mathrm{l} \mathrm{kg}^{-1}$ ) compared with published mean values for normal volunteers of $1.871 \mathrm{~kg}^{-1}$ (Garg et al., 1981) and 1061 (Young et al., 1982). Volume of the initial dilution space ranged from $17-924 \mathrm{ml} \mathrm{kg}^{-1}$ (median $\left.=89 \mathrm{ml} \mathrm{kg}^{-1}\right)$ compared to the mean value of $163 \mathrm{ml} \mathrm{kg}^{-1}$ in normal volunteer subjects (Chau et al., 1982). Half-life in the critically ill patients (median $=4.7 \mathrm{~h}$ ) was some two to three fold longer than the range of means of 1.7-2.2 $\mathrm{h}$ in normal volunteers (McNeil et al., 1981; Garg et al., 1981; Lebert et al., 1981a; Van Hecken et al., 1982; Young et al., 1982; McGonigle et al., 1982) but was closer to that for patients with renal impairment (5.3 h, Meffin et al., 1983; $7.3 \mathrm{~h}$, McFadyen et al., 1983). Plasma clearance in the critically ill (median $=4.22 \mathrm{ml} \mathrm{min}^{-1} \mathrm{~kg}^{-1}$ ) was about one half that for normal volunteer subjects (range of means $=8.9-10.4 \mathrm{ml} \mathrm{min}^{-1}$ $\mathrm{kg}^{-1}$; Lebert et al., 1981a,b; Chau et al., 1982; Garg et al., 1981) and again was closer to the mean of $5 \mathrm{ml} \mathrm{min}^{-1} \mathrm{~kg}^{-1}$ which can be calculated from the data of Meffin et al. (1983) in patients with renal impairment. However, it should be noted that our critically ill patients showed wide inter-patient variability in both clearance and half-life with an approximate 8-12 fold range for these parameters. In renal disease, clearance has been reported to vary over a 5 fold range (Meffin et al., 1983) while in other studies half-life varied over a 1.4-5.2 fold range (McGonigle et al, 1982; McFadyen et al, 1983). In hepatic cirrhosis, Smith et al., 1984) found a 2 fold variation in clearance values for their patients.

On the basis of clinical laboratory test data, patients KK, BB, JJ, RR, AR, AS, RW and TH were known to have renal impairment. Mean clearance for ranitidine in these patients was $3.39 \pm 0.55 \mathrm{ml} \mathrm{min}^{-1} \mathrm{~kg}^{-1}$ and was significantly lower $(t=2.23, P<0.05)$ than in the remaining patients $\left(5.2 \pm 0.58 \mathrm{ml} \mathrm{min}^{-1} \mathrm{~kg}^{-1}\right)$. Considering the whole group of patients, all but two had estimated creatinine clearance values which were below or at the lower end of the range for healthy subjects. Hence, it would seem that impaired renal excretion is an important factor in the low ranitidine clearance in our patients.

The correlation between ranitidine clearance and estimated creatinine clearance in the present study is in agreement with previous data (Meffin et al., 1983) but should be interpreted cautiously as there may be variability in estimation of creatinine clearance in critically ill patients. Renal clearance accounts for about $70 \%$ of the total body clearance of ranitidine in healthy volunteers (Chau et al., 1982) while metabolic (hepatic) clearance presumably accounts for the balance of ranitidine clearance. Our data suggest that reduced renal clearance is an important factor in the low total body clearance observed in our patients. Reduced hepatic metabolism is less likely to be a major factor but cannot be entirely excluded since recent studies have shown that hepatic cirrhosis in patients with normal renal function results in a mild to moderate impairment of ranitidine plasma clearance (Young et al., 1982; Smith et al., 1984).

Although a gastric pH of 5 is the suggested goal of antacid therapy, a cut-off point of $\mathrm{pH} 4$ was chosen in the present study on the basis that Hastings et al., (1978) found that a pH of 3.5 was adequate to control stress bleeding, and on the finding that $\mathrm{pH}$ levels of 5-6 are not readily obtainable with the related histamine $\mathrm{H}_{2}$ receptor blocking drug cimetidine (Priebe et al., 1980; Stothert et al., 1980). The data in Figure 2 indicate that $\mathrm{pH}$ measurements at 0,1 and $7 \mathrm{~h}$ after ranitidine dosage are representative of the $\mathrm{pH}$ profile throughout the dose interval. The question of whether ranitidine maintenance dose should be reduced in this patient group is not easy to answer since overall only $58 \%$ of gastric aspirate samples had $\mathrm{pH}$ values which were compatible with effective suppression of acid secretion (i.e., $\mathrm{pH}>4$ ). This response rate occurred despite trough plasma ranitidine concentrations which were similar to (median = $0.11 \mathrm{mg} \mathrm{l}^{-1}$, range $=0.05-1.44 \mathrm{mg} \mathrm{l}^{-1}$ ) those required to cause a $50 \%$ suppression of gastric acid secretion (range of means $=0.073-0.2 \mathrm{mg}$ $1^{-1}$ ) in healthy volunteers (Lebert et al., 1981b; Mignon et al., 1982; Holloway et al., 1984). Moreover, four of our patients failed to achieve significant elevation of gastric $\mathrm{pH}$ at any of the times at which measurements were made. At first glance these results appear to conflict with a study by Macchi et al. (1982) in a similar group of patients in which both 10 and $20 \mathrm{mg}$ doses of intravenous ranitidine given 8 hourly kept gastric $\mathrm{pH}$ above 5 for a mean of $18-19 \mathrm{~h} \mathrm{day}^{-1}$ with a range of between 2 and $23 \mathrm{~h}$. However, More $e t$ al. (1985) also reported considerable difficulty in maintaining gastric $\mathrm{pH}$ above 4 in critically ill patients despite a total daily dosage of between 200 and $600 \mathrm{mg}$ ranitidine. It is interesting to 
to note that mean plasma ranitidine concentration in our patients was similar irrespective of whether corresponding gastric $\mathrm{pH}$ was above or below 4 . Further work is therefore necessary to quantify the plasma concentration-response relationship for ranitidine in critically ill patients and to identify

\section{References}

Barth, H. O., Berg, P., Brunner, G., Dammann, H. G., Friedl, W., Franken, F. H., Greiner, L., Groitl, J., Mockel, W., \& Muller, P. (1984). Ranitidine and cimetidine in the prevention of stress ulcer hemorrhage-a prospective comparative multicentre study. Langenbecks Arch. Chir., 362, 131-138.

Bjornsson, T. D., Cocchetto, D. M., McGowan, F. X., Verghese, C. P. \& Sedor, F. (1983). Nomogram for estimating creatinine clearance. Clin. Pharmacokin., 8, 365-369.

Brogden, R. N., Carmine, A. A., Heel, R. C., Speight, T. M. \& Avery, G. S. (1982). Ranitidine: A review of its pharmacology and therapeutic use in peptic ulcer disease and other allied diseases. Drugs, 24, 267-303.

Chau, N. P., Zech, P. Y., Pozet, N. \& Hadj-Aissa, A. (1982). Ranitidine kinetics in normal subjects. Clin. Pharmac. Ther., 31, 770-774.

Garg, D. C., Weidler, M. D., Baltodano, N. \& Eshelman, F. N. (1981). Pharmacokinetics of ranitidine, a new histamine $\mathrm{H}_{2}$-receptor blocker. Clin. Pharmac. Ther., 29, 247-248.

Greene, W. L. \& Bollinger, R. R. (1984). Cimetidine for stress-ulcer prophylaxis. Critical Care Medicine, 12, 571-575.

Hastings, P. R., Skillman, J. J., Bushnell, L. S. \& Silen, W. (1978). Antacid titration in the prevention of acute gastrointestinal bleeding: A controlled, randomized trial in 100 critically-ill patients. New Engl. J. Med., 298, 1041-1045.

Holloway, R. H., Kuljian, B., Eshelman, F. \& McCallum, R. W. (1984). Effects of ranitidine and cimetidine on pentagastrin-stimulated gastric acid secretion. Clin. Pharmac. Ther., 35, 203-207.

Lebert, P. A., Mahon, W. A., MacLeod, S. M., Soldin, S. J., Fenje, P. \& Vandenberghe, H. M. (1981a). Ranitidine kinetics and dynamics. II. Intravenous dose studies and comparison with cimetidine. Clin. Pharmac. Ther., 30, 545-550.

Lebert, P. A., Mahon, W. A., MacLeod, S. M., Soldin, S. J., Fenje, P. \& Vandenberghe, H. M. (1981b). Ranitidine kinetics and dynamics. I. Oral dose studies. Clin. Pharmac. Ther., 30, 539-544.

Macchi, H., Fiasse, R., Reynaert, M., Desager, J. P. \& Dive, C. (1982). Effect of ranitidine (inhibitor of $\mathrm{H}_{2}$-receptors) after i.v. injection to patients treated in an intensive care unit: control of gastric acid secretions and estimation of drug plasma levels. Arch. int. Pharmacodyn. Ther., 256, 306-307.

McFadyen, M. L., Folb, P. I., Miller, R., Keeton, possible subgroups of non-responders who may require additional anti-ulcer prophylaxis.

We are grateful to Glaxo Australia for supplying ranitidine, desmethylranitidine and AH20480 analytical standards and for financial support of the project.

G. R. \& Marks, I. N. (1983). Pharmacokinetics of ranitidine in patients with chronic renal failure. Eur. J. clin. Pharmac., 25, 347-351.

McGonigle, R. J. S., Williams, L. C., Amphlett, G. E., England, R. J. \& Parsons, V. (1982). The pharmacokinetics of ranitidine in renal disease. In The clinical use of ranitidine, eds. Misiewicz, J. J. \& Wormsley, K. Medicine Publishing Foundation Series 5, pp. 41-46. Oxford: Medicine Publishing Foundation.

McNeil, J. J., Mihaly, G. W., Anderson, A., Marshall, A. W., Smallwood, R. A. \& Louis, W. J. (1981). Pharmacokinetics of the $\mathrm{H}_{2}$-receptor antagonist ranitidine in man. Br. J. clin. Pharmac., 12, 411415.

Meffin, P. J., Grgurinovich, N., Brooks, P. M., Miners, J. O., Cochran, M. \& Stranks, G. (1983). Ranitidine disposition in patients with renal impairment. Br. J. clin. Pharmac., 16, 731-734.

Metzler, C. M. (1969). Nonlin, a computer program for parameter estimations in nonlinear situations. Kalamazoo, Michigan, U.S.A: Upjohn Co.

Mignon, M., Chau, N. P., Nguyen-Phuoc, B. K., Sauvage, M., Leguy, F. \& Bonfils, S. (1982). Ranitidine upon meal-induced gastric secretion: oral pharmacokinetics and plasma concentration effect relationships. Br. J. clin. Pharmac., 14, 187193.

More, D. G., Raper, R. F., Watson, C. J. \& Shenfield, G. S. (1985). Combination therapy with ranitidine and pirenzepine for control of intragastric $\mathrm{pH}$ in the critically ill. Critical Care Medicine (in press).

Priebe, H. J., Skillman, J. J., Bushnell, L. S., Long, P. S. \& Silen, W. (1980). Antacid versus cimetidine in preventing acute gastrointestinal bleeding. A randomised trial in 75 critically-ill patients. New Engl. J. Med., 302, 426-430.

Smith, I. L., Ziemniak, J. A., Bernhard, H., Eshelman, F. N., Martin, L. E. \& Schentag, J. J. (1984). Ranitidine disposition and systemic availability in hepatic cirrhosis. Clin. Pharmac. Ther., $35,487-494$.

Stothert, J. C. Jr., Simonowitz, D. A., Dellinger, E. P., Farley, M., Edwards, W. A., Blair, A. D., Cutler, R. \& Carrico, C. J. (1980). Randomised prospective evaluation of cimetidine and antacid control of gastric $\mathrm{pH}$ in the critically ill. Ann. Surg., 192, 169-174.

Van Hecken, A. M., Tjandramaga, T. B., Mullie, A., Vanbesselt, R. \& de Schepper, P. J. (1982). 
Ranitidine: single dose pharmacokinetics and absolute bioavailability in man. Br. J. clin. Pharmac., 14, 195-200.

Wagner, J. G. (1976). Linear pharmacokinetic equations allowing direct calculation of many needed pharmacokinetic parameters from the coefficients and exponents of the polyexponential equations which have been fitted to the data. J. Pharmacokin. Biopharm., 4, 443-467.
Young, C. J., Daneshmend, T. K. \& Roberts, C. J. C. (1982). Effects of cirrhosis and ageing on the elimination and bioavailability of ranitidine. Gut, 23, 819-823.

(Received 3 July 1985, accepted 15 October 1985) 